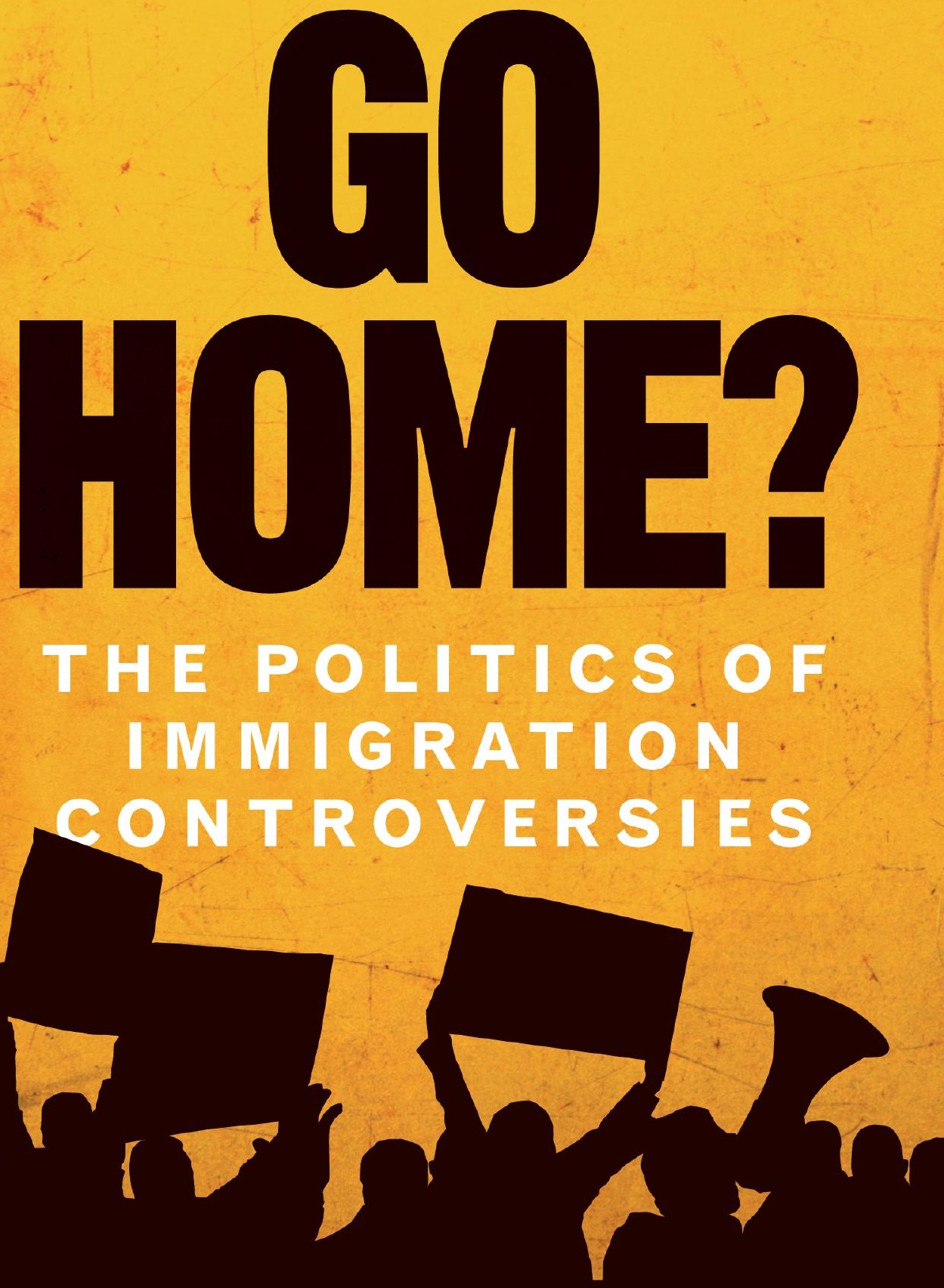

'The kind of research that will help to craft new forms of politics and ways of imagining the future.' 


\section{Go home?}

\section{MANCHESTER 1824}

Manchester University Press 
argi Bhattacharyya, William Davies, Sukhwant Dhaliwal, Emma Jackson, and Roiyah Saltus - 9781526117946 Downloaded from manchesterhive.com at 04/26/2023 05:47:47AM 


\section{GO HOME?}

\section{The politics of immigration controversies}

Hannah Jones, Yasmin Gunaratnam, Gargi Bhattacharyya, William Davies, Sukhwant Dhaliwal, Kirsten Forkert, Emma Jackson and Roiyah Saltus 
Copyright (C) Hannah Jones, Yasmin Gunaratnam, Gargi Bhattacharyya, William Davies, Sukhwant Dhaliwal, Kirsten Forkert, Emma Jackson and Roiyah Saltus 2017

The rights of Hannah Jones, Yasmin Gunaratnam, Gargi Bhattacharyya, William Davies, Sukhwant Dhaliwal, Kirsten Forkert, Emma Jackson and Roiyah Saltus to be identified as the authors of this work have been asserted by them in accordance with the Copyright, Designs and Patents Act 1988.

Published by Manchester University Press

Altrincham Street, Manchester M1 7JA

www.manchesteruniversitypress.co.uk

British Library Cataloguing-in-Publication Data

A catalogue record for this book is available from the British Library

Library of Congress Cataloging-in-Publication Data applied for

ISBN 9781526113214 hardback

ISBN 9781526113221 paperback

ISBN 9781526117946 open access

First published 2017

An electronic version of this book is also available under a Creative Commons (CC-BY-NC-ND) licence

The publisher has no responsibility for the persistence or accuracy of URLs for any external or third-party internet websites referred to in this book, and does not guarantee that any content on such websites is, or will remain, accurate or appropriate.

Typeset

by Toppan Best-set Premedia Limited 